\title{
Molecular Confirmation of Salmonella typhimuriumin Poultry from Kathmandu Valley
}

Sanjeev Kumar Adhikari ${ }^{1 *}$, Arrogya Gyawali ${ }^{{ }^{*}}$, Sajan Shrestha ${ }^{1 *}$, Swoyam Prakash Shrestha ${ }^{2}$, Meera Prajapati ${ }^{2}$ and Doj Raj $\mathrm{Khanal}^{2 @}$

${ }^{1}$ SANN International College, Purbanchal University, Gairidhara, Kathmandu; SA <adhikarisanjeev4@gmail.com>;

AG <arrog77@gmail.com>; SS <sajandale@gmail.com>

${ }^{2}$ Animal Health Research Division, Nepal Agricultural Research Council, Lalitpur, Nepal; SPS<swoyamsp@yahoo.com> @: drkhanal7@gmail.com

*These authors have equal contribution

Received 24 Feb 2018, Revised 25 March 2018, Accepted 30 March 2018, Published 28 April 2018

Scientific Editors : Damodar Sedhai and Bal K. Joshi

Copyright $\odot 2018$ NARC. Permits unrestricted use, distribution and reproduction in

any medium provided the original work is properly cited.

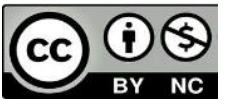

OPEN ACCESS

Licensed under the Creative Commons AttributionNonCommercial 4.0 International (CC BY-NC 4.0)

\begin{abstract}
A prevalence study was carried to isolate Salmonella typhimurium from blood $(n=50)$ and gut samples $(n=100)$ of poultry in Kathmandu valley during early 2016. Salmonella typhimurium bacteria isolated in the selective media were biochemically confirmed based on Bergey's Manual. Two sets of oligonucleotide primers-the genus specific 16S rRNA and the organism specific invA were employed for molecular level confirmation by the Polymerase Chain Reaction (PCR) assay. The amplified fragments in $1 \%$ agarose gel observed at $406 \mathrm{bp}$ and $285 \mathrm{bp}$, respectively confirmed the isolates to be Salmonella typhimurium. Of 150 samples tested, Salmonella typhimurium were isolated from 49 samples, among which nine were from blood (18\%) and forty from the gut (40\%). The present result indicated an alarmingly high level of Salmonella typhimurium, which can result inzoonotic infection in humans owing to increased contact with poultry and consumption of poultry products in the Kathmandu valley.
\end{abstract}

Keywords: Salmonella typhimurium, invA, Invasion, Polymerase Chain Reaction (PCR)

सारंश

वि.सं.२०७३ सालमा काठमाडौं उपत्यकाको बिभिन्न मासु पसलहरुको स्थलगत भ्रमण गरि पू० वटा कुखुराहरुबाट रगत र १०० वटा कुखुराहरुबाट सुलीको नमुनाहरु संकलन गरि पशु स्वास्थ्य अनुसन्धान महाशाखाको प्रयोगशालामा मानिसमा पनि सर्न सक्ने साल्मोनेल्ला टाइफिमुरियम नामक जीवाणुको संक्रमणको यथास्थिति के छ, भनी अनुसन्धान गर्ने काम भयो । सो परिक्षणको ऋममा $९$ वटा रगत $(9 ५ \%)$ र ४० (४०\%) वटा सुलीको नमुनाहरुमा उक्त साल्मोनेल्ला टाइफिमुरियम जीवाणु भएको तथ्य बायोकेमिकल र अणुबंशिक प्रविधिद्वारा (पोलीमरेज चैन रेयाक्सन:(PCR) पुष्टी भयो। यस नतिजाले अव्यवस्थित तरिकाले कुखुरा पालन गर्दा मानिसमा सर्न सक्ने टाइफाइड रोगको जोखिम उच्च रहेको तथ्य उजागर भएको छ।

\section{INTRODUCTION}

Poultry industry has been expanding rapidly in the recent days. Average poultry consumption in Kathmandu valley alone is greater than rest of the country. There are increasing number of slaughter places in the valley with different levels of hygiene and mostly adopting poor bio-security practices. Good farming practice (GFP) with hygienic production at all scale is a must for booming industry (CPS 2016). Salmonellosis caused by Salmonella typhimurium is a disease of economic and zoonotic importance. Salmonella outbreaks are often linked to unhygienic food preparation, sanitation and storage practices. Noteworthily, a Gram-negative, facultative anaerobe and flagellated Salmonella typhimurium bacterium is a major cause of enteric illness and typhoid fever which can lead to many hospitalizations and a few rare deaths, if no antibiotics are administered (Le Minor 1992).

Poultry is one of the major reservoirs of Salmonella typhimurium which shares most salmonellosis cases encountered globally. This nature of the enteric non-typhoidal strain is attributed to its wide range of host specificity which has even led to its diverse range of zoonosis. They are the third most common serovar causing human food poisoning in different parts of the world (Francis et al 2009). Apart from this, they are pathogenic agent for systemic illness like typhoid fever in cow and mouse. In recent times, multi drug resistance is a highly 
discussed topic, with increased concerns for antibiotic resistance while tackling salmonellosis in humans. This constitutes a major public health burden and represents a significant cost to urban society.

Polymerase chain reaction (PCR) has been a new avenue in the detection of Salmonella. PCR methodology has been successfully adapted for rapid identification of Salmonella typhimurium based on a gene sequence invA, that is unique to its genotype. A gene, invasion protein A (invA) is targeted for Salmonella identification since this gene was shown to be present in many Salmonella strains (Rahn et al 992). The detection of Salmonella therefore, remains a highly important issue in microbiological analysis for ensuring food safety and standards (Ammar et al 2010). Due to higher accuracy and precision of molecular techniques, current study was aimed at diagnosing Salmonella typhimurium bacterium using PCR assay. This novel method can thus be the steward approach to assess the hygienic status of the retail meats sold at urban areas like Kathmandu valley.

\section{MATERIALS AND METHODS}

Sample collection

One hundred fifty samples of retail chicken including blood (50) and gut (100) were collected from different slaughter places at Kathmandu (50), Poultry Farm at Lalitpur (40) and Poultry House at Bhaktapur (60) in sterilized EDTA tubes and transferred to AHRD in ice box. Professional veterinarian was employed for blood collection after following proper ethical guidelines.

\section{Isolation and identification of Salmonella spp}

Pre-enrichment of the collected samples were done in the non-selective medium followed by selective ones for isolation of the organisms. Briefly, buffered peptone water was used for enrichment of Salmonella spp. followed by Rappaport Vassiliades Soy (RVS) peptone broth and the Xylose-Lysin Deoxycholate (XLD) agar for the isolation and enumeration of Salmonella species. The brilliant green agar(BGA) was used for the selective isolation of Salmonella other than S. typhi and the MacConkeyagar for the isolation and differentiation of lactose fermenting and lactose non-fermenting enteric bacteria. Colonies of typical growth were picked up and confirmed morphologically (Quinn et al 1994) and biochemically by Indole production, Methyl red,VogesProskauer, $\mathrm{H}_{2} \mathrm{~S}$ production on TSI agar, Citrate utilization, catalase, oxidase, urease and sugar (dextrose, lactose, sucrose, mannitol and maltose fermentation tests (Oliviera et al 2003) as given in Table 2.

\section{Specific Primers Sequence Used for PCR Amplification}

The primers used for the detection of specific sequence of $16 \mathrm{SrRNA}$ ribosomal genes (Baay et al 1993) and invA gene (White et al 2002) of Salmonella spp. were procured from Macrogen, Korea as listed in the Table 1.

Table 1. Primers used for the detection specific sequence of $16 \mathrm{SrRNA}$ and invA genes.

\begin{tabular}{llr}
\hline Target gene & Primer Set & $\begin{array}{r}\text { Amplicon } \\
(\mathbf{b p})\end{array}$ \\
\hline invA & Forward: 5'-GTG AAA TTA TCG CCA CGT TCG GGC AA-3' & 285 \\
& Reverse: 5'-TCA TCG CAC CGT CAA AGG AAC C-3' & 406 \\
\multirow{2}{*}{$16 s r R N A$} & $\begin{array}{l}\text { Forward: 5'-CGG ACG GGT GAG TAA TGT CT-3' } \\
\text { Reverse: 5'-GTTAGCCGGTGCTTCTTC TG-3' }\end{array}$ & \\
\hline
\end{tabular}

DNA extraction

Genomic DNA was extracted from suspected isolates for the molecular confirmation of the strain. The DNA of 14028s strain of Salmonella typhimurium, which was a generous gift from Professor Kunihiko Nishino of University of Osaka, Japan was also extracted using Qiagen DNA mini-kit. This was used as positive control for characterization.

Preparation of master mix for Detection of 16s rRNA and invA genes

For the detection of Salmonella spp. and S. typhimurium by PCR, 2X PCR master mix from Bioneer, Korea was used. The components of the master mix include bacterially derived Taq DNA polymerase, each deoxynucleotides (dNTPS), Tris-HCL ( $\mathrm{pH}-9), \mathrm{MgCl}_{2}, \mathrm{KCl}$ and stabilizer and tracking dye. The PCR amplification mixture $(25 \mu \mathrm{l})$ which was used for the detection of each gene includes $13 \mu \mathrm{l}$ of PCR Master Mix, $5 \mu \mathrm{l}$ of template DNA, $1.5 \mu \mathrm{l}$ of each forward and reverse primers and $5 \mu \mathrm{l}$ molecular grade nuclease free water. The PCR tubes containing an amplification mixture were transferred to thermocycler that was programmed for amplification of the 16srRNA and invAgenes. The DNA was initially denatured for 5 minutes at $95^{\circ} \mathrm{C}$ followed by 35 cycles of denaturation at $95^{\circ} \mathrm{C}$ for 1 minute, annealing at $50^{\circ} \mathrm{C}$ for 1 minute, and extension at $72^{\circ} \mathrm{C}$ for 2 minutes. The final extension was held at $72^{\circ} \mathrm{C}$ for 10 minutes. The amplified DNA products from Salmonella 
spp. specific-PCR were analyzed with electrophoresis on $1 \%$ agarose gel stained with ethidium bromide (10 $\mathrm{mg} / \mathrm{ml}$ ) and visualized under UV illumination by comparing with $1000 \mathrm{bp}$ DNA ladder.

\section{RESULTS}

Out of 150 chicken samples (blood and gut), S. typhimuriumwas detected in $18 \%$ blood and $40 \%$ gut samples based on biochemical characteristics (Table 2 and Table 3) and PCR characterization (Figure 1).

Table 2. Biochemical characteristics of suspected isolates of Salmonella spp.

\begin{tabular}{lr}
\hline Biochemical test & Result (+ positive; - negative) \\
\hline Methyl Red & + \\
\hline Voges Proskauer & - \\
\hline $\mathrm{H}_{2} \mathrm{~S}$ Production on TSI Agar & + \\
\hline Indol Production & - \\
\hline Catalase & + \\
\hline Oxidase & - \\
\hline Citrate Utilization & + \\
\hline
\end{tabular}

Table 3. Incidence of S. typhimuriumin the examined samples

\begin{tabular}{|c|c|c|c|}
\hline \multirow[t]{2}{*}{ Sample } & \multicolumn{2}{|c|}{ Incidence of $S$. typhimurium } & \multirow[t]{2}{*}{ Percentage $(\%)$} \\
\hline & Number & Positive & \\
\hline Gut & 100 & 40 & 40 \\
\hline Blood & 50 & 9 & 18 \\
\hline
\end{tabular}
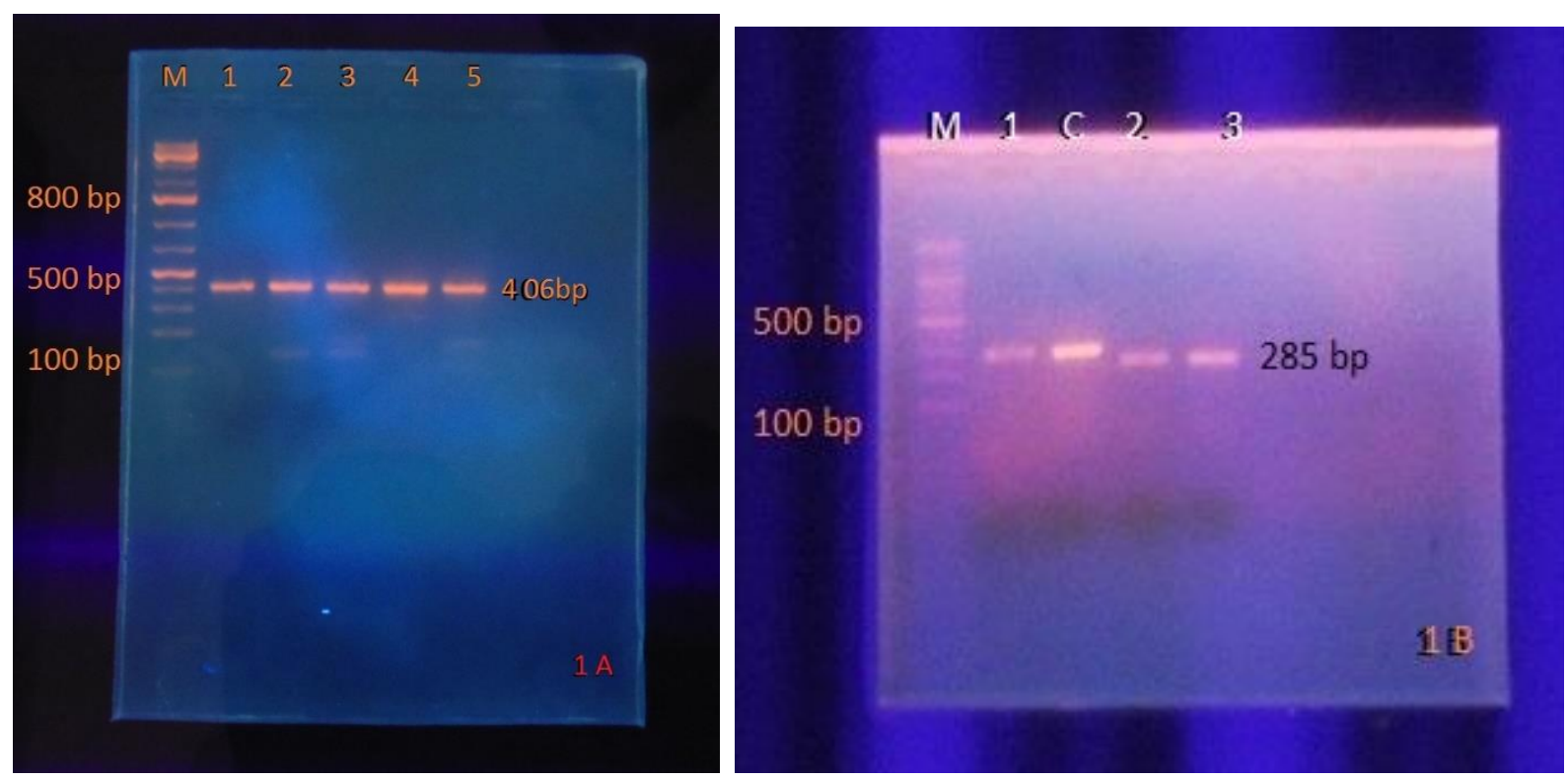

Figure 1A and 1B: Gel showing PCR products of DNA extracted from Salmonella strains for detection of 16 srRNA and invA genes, respectively. Lanes M: 100-bp DNA marker; Figure 1A showing band of Salmonella species in lanes 1-5(406 bp); Figure 1B showing band of S. typhimuriumin lanes 1-3(285 bp); C: positive control of S. typhimurium.

\section{DISCUSSION}

In the present study, the incidence of S. typhimurium in raw chicken gut and blood were $40 \%$ and $18 \%$, respectively. Abdellah et al (2009) reported Salmonella contamination in chicken meat and giblets with identification of 4 different serotypes, of which S. typhimurium $(40.35 \%)$ was the most frequently detected. Higher levels of Salmonella were isolated with the incidence of 86\% (190/221) and 42\% (24/57) in chicken meat and giblets, respectively (Jerngklinchan et al 1994). Salmonella isolated at higher rate from chicken meat than giblet may be because defeathering process can spread microorganisms between carcasses or from the defeathering equipment contributing to an increase in the numbers of psychrotrophs and aerobic mesophiles on the carcasses. The evisceration process provides an opportunity for cross contamination from human, equipment and worker's hands (Jackson et al 2001). The present finding could also be due to poor hygienic condition of retail shops, though it needs to be verified independently. S. typhimurium as multidrug resistant strain is causing huge menace to public that could have been attributed by the oral supplementation of antibiotics in poultry 
feeds. With unhygienic poultry production, it all comes to how well they thrive shifting the advantage to their favour and develop resistance in the long run.

Flocks of chicken reared on antibiotics in feed to enhance growth promotion and prevent disease outbreaks are developing drug resistance against many bacterial pathogens including Salmonella typhimurium. Higher prevalence of $S$. typhimurium as confirmed in the present study by PCR assay for the first time in Nepal from raw chicken gut and blood invokes more challenges and threats to economics of poultry production and safeguarding public health.

\section{ACKNOWLEDGEMENTS}

Our appreciation is to Dr. Ivancho Naletoski, TO, International Atomic Energy Agency (IAEA), Vienna, Mr. Dilip Bhattarai, Mr. Keshab Buda, Mr. Lalit Man Shrestha from Animal Health Research Division and Science of Ancient and New Nepal (SANN) International College.

\section{REFERENCES}

Abdellah C, RF Fouzia, C Abdelkader, SB Rachida and Z Mouloud. 2009. Prevalence and anti-microbial susceptibility of Salmonella isolates from chicken carcasses and giblets in Meknes, Morocco. Afr. J. Microbiol. Res. 3:215-219.

Ammar A, A Ahmed, A Asawy and A Ibrahim. 2010. Bacteriological studies on salmonella enteritis isolated from different sources in Dakhlia Governorate, Assiut Vet. Med. J. 56 (124): 125-135.

Baay MF and JH Veld. 1993. Alternative antigens reduce cross-reactions in an ELISA for the detection of Salmonella enteritidis in poultry. J Appl. Bacteriol. 74: 243-247.

Commercial Poultry Survey (CPS). 2016. Nepal's Poultry Industry worth Rs33.72 Billion http://kathmandupost.ekantipur.com/news/2016-07-10/nepals-poultry-industry-worth-rs3372-billion.html;Published: 10-07-2016 09:22 Assessed on: 2017/01/24

Jackson TC, DL Marshall, GR Acuff and JS Dickson. 2001. Meat, poultry and seafood. In: Food microbiology, fundamentals and frontiers (MP Doyle, LR Beuchat and TJ Montville 2nd ed). Washington DC: ASM. Press; pp. 91109.

Jerngklinchan J, C Koowatananukul, K Daengprom and K Saitanu.1994.Occurrence of Salmonellae in raw broilers and their products in Thailand. J Food Prot. 57: 808-810.

Rahn K, SA De Grandis, RC Clarke, SA McEwen, JE Galan, C Ginocchio, R Curtiss and CL Gyles.1992. Amplification of an invA gene sequence of Salmonella typhimurium by polymerase chain reaction as a specific method of detection of Salmonella. Mol Cells Probes. 6: 271-279.

Le Minor M. 1992.The genus Salmonella. In: The Prokaryotes (A Balows, HG Truper, M Daworkin, W Harder, KH Schleifer eds.), New York, Springer-Verlag. pp. 2760-2774.

Oliveira S, M Rodenbusch, L Rocha and C Canal. 2003. Evaluation of selective and non-selective enrichment PCR Procedures for Salmonella detection. Lett. Appl. Microbiol. 36: 217-221.

Quinn PJ, ME Carter, BK Markey and G Carter.1994. Clinical Veterinary Microbiology. Mosby Year Book Europe Ltd.

White P, K Meglli, D Collins and E Gormely. 2002. The prevalence and PCR detection of Salmonella contamination in raw poultry. Vet. Microbiol. 89: 53-60. 